\title{
Pilot Project Intervention of Nutrition and Health Education for Mother and Provision of Energy-Dense Cookies in Early Childhood to Improve Their Nutritional Status
}

\author{
Siti Fathonah ${ }^{1}$, Sarwi $^{1}$, Rosidah $^{1}$, Aris Handoyo ${ }^{1}$ dan Titis Budi Rahayu ${ }^{1}$ \\ Home Economic Departement, Universitas Negeri Yogyakarta, Semarang, Indonesia \\ fathonah@mail.unnes.ac.id
}

Keyword: Interventions, early childhood, nutrition and health education, energy-dense biscuits

Abstract: $\quad$ The purpose of this study was to determine the impact of nutrition and health education interventions and provision of energy-dense biscuits on the nutritional status in early childhood. Intervention nutrition education is done by 1) nutrition and health education for $2 \times 2$ hours and giving a practical guide book "Nutrition and Health for the Early Childhood" to the teacher and early childhood's mother to be learned and applied in parenting, in two different early childhood education in Semarang, 2) the provision of energydense biscuits made of cornstarch (50\%), mung bean flour (60\%) and purple parsnip flour (50\%) on early childhood for 30 days @ $20 \mathrm{~g}$. To determine the effectiveness of interventions performed by N-gain calculation and difference test by "paired samples t-test". The results showed that 1) the intervention improves nutritional and health knowledge as well as knowledge of snack food on teachers and early childhood's mother with $\mathrm{N}$-gain respectively 0.50 and 0.34 (medium category) and differed significantly ( $\mathrm{p}=$ $0.000), 2$ ) intervention increases early childhood's nutritional status towards good nutritional status/normal and significantly different with $\mathrm{p}=0.034$. After the intervention of the early childhood's nutritional status, the children with normal nutritional status is $90.4 \%$ (up to 6,2 \%), wasting 6.3\% (down to $6.2 \%$ ) and obesity 3.1 $\%$ (constant).

\section{INTRODUCTION}

Early age in the process child growth and development is the most critical period for the outgrowth that occurs within the first 4 years. Intellectual stimulation to support growth is very fundamental. If it's not provided adequate nutrition and a high health status, then brain's capacity can't be maximumly formed (Jalal, 2002). According to the data from the Health Research in 2010, the number of patients with under-weight among early childhood or toddlers reach out consists of $4.9 \%$ malnutrition and $13.0 \%$ lack-nutrition, while the prevalence of obesity by $14 \%$ (Ministry of Health, 2013). This condition is also still going on in various parts of the world, amongst obesity of school children in the United States around 30\% and 20\% in Europe (Lobstein, 2004), 25\% in Australia (Booth, 2004) and 20\% of preschool children (Wake, 2007) of stunting in Tanzania among children aged 6-59 months in the national surveys of 2005 and 2009/2010 was $37.7 \%$ and $42 \%$, respectively. Children in rural areas were more affected than urban Reviews their peers $(40.5 \%$ vs. $37.7 \%$ in $2005 ; 44.7 \%$ vs $32.1 \%$ in 2010) (Kulwa et.al, 2014). Early childhood conditions in Semarang, malnutrition is higher of $21,6 \%$, with details of $14,5 \%$ wasting and $8,5 \%$ severe wasting. But otherwise, the prevalence of obesity is $5,0 \%$ (Fathonah, et al 2014). The conditions need to be improved with the efforts so that the early childhood become a qualified generation in nutrition, health and their intellectual.

Efforts that have been performed in many countries produces a positive impact on early childhood development. Health and nutrition interventions in preschool children in developing countries have a considerable effect and consistent in development and education. All the good aspects of cognitive, motor, social and emotional, and the biggest developments in the motor aspects (Yukes, 2007). Intervention NAP SACC (Nutrition and Physical Activity Self-Assessment for Child Care) in California showed a significant increase in knowledge of nutrition and physical activity of the child care providers and parents, the center of 
effect of mother's education interventions and the provision of energy-dense biscuits on early childhood's nutritional status. With these interventions are expected to improve the quality of life for the early childhoodss to be the younger generation that has character and quality. were 1.1 (28.3 to 29.2), while the control group increased by 0.3 ((27.3 to 27.6). The intervention group claimed $39.6 \%$ of children have always eaten with a healthy diet and $35.7 \%$ tried to eat with a healthy diet, while the control group $(34.4 \%$ and $31.7 \%$ ) (Lakshman et al, 2010). Intervention for 6 months with nutrition and physical activity program with a home-based strategy done on mothers of toddlers in Perth, Western Australia. The results of the intervention showed significant improvements diet in a positive direction (Jancey et al, 2014). Nutrition education interventions in women with overweight/obese who have a toddler (2-5 years) who are malnourished in rural areas in Indonesia for 6 months have a positive impact. Intervention can help mothers decide for themselves a good diet and behavior in feeding her child (Mahmudiono et al., 2016).

Interventions that less successful such intervention of a healthy diet (healthy eating habits) on elementary school children in poor families in southern Africa showed no significant changes in scores diversity of food consumption (Dietary Diversity Score/DDS) (Steyn et al, 2015).

Interventions that have done it over on nutrition and health education course. In this research, the two activities together that nutrition and health education teacher and mother of early childhood and the provision of energy dense biscuits.

Research that has been done by Fathonah, et al (2015) has produced a practical handbook on nutrition and health for the early childhood intended for teachers and mothers of young children. A healthy snack food such as energydense biscuits has been made by mung bean flour, corn flour and purple parsnip flour. These three categories of energy-dense biscuits including the energy content of more than $400 \mathrm{kcal}$, protein content and high fiber too (Fathonah and Sari, 2015, and Fathonah and Muvida, 2015) that has been produced by small industries.

Both activities are followed by a pilot project to implement the early childhood in two early childhood education in Semarang. The purpose of the study was to determine 1) the effect of nutrition education interventions to increase mother's knowledge of nutrition, 2) the effect of mother's nutrition education on early childhood's nutritional status, 3) the effect of energy-dense biscuits on early childhood's nutritional status, and 4) the

\section{METHODE}

\subsection{Research's Subject}

Subjects were stakeholders in a practical handbook and Health Nutrition Education for the early Childhood, namely early childhood teachers, parents and early childhood experts from Universities. Home industry-based biscuit's production is done by Shella Cookies in Semarang. Early childhood practical guide line's trial was done in two Early Childhood School in Semarang.

\subsection{Intervention}

a. Practical handbook has been compiled and evaluated and validated through focus group discussions with teachers of early childhood education, early childhood education's lecturers from universities, and early childhood's mothers. The practical handbook contains 1) basic nutrition, 2) street food, 3) early childhood's nutritional problems and 4) healthy snack foods.

b. Nutrition and health education intervention. The intervention is done to all teachers and early childhood's mothers at two early childhood's school. Nutrition education has given in $2 \times 2$ hours refers to the practical handbook and a book is given to be learned and applied in everyday parenting.

c. Production of biscuits with three kinds of raw materials namely corn, purple parsnip and green bean biscuits. Biscuits are given as much as 20 grams by turns each day. Biscuits were given for 30 days in a row. All three biscuits characterized by high energy biscuits with > $400 \mathrm{kcal} / 100 \mathrm{~g}$. The advantages of corn biscuits are high-beta-carotene $2.721-4.134$ $\square \mathrm{g}$, green beans biscuits contain high protein 10.6 to $11.3 \%$, and crude fiber $9.5-13.2 \%$, while the purple parsnip biscuits contain high crude fiber $8.3-10.1 \%$, and antocyanin 41.6 to $46.7 \mathrm{ppm}$.

d. Mother's knowledge of nutrition and health and the knowledge snack food was measured by a questionnaire, and early childhood's nutritional status was measured by Body Mass Index, 
conducted before and after implementation of the intervention.

\subsection{Data Analysis Technique}

To determine the effectiveness of pilot activities practical handbook Nutrition and Health Education for Early Childhood and the provision of energydense biscuits made with N-gain (Hake, 1998) and the difference test with paired samples t-test (Kadir, 2015).

\section{RESULTS AND DISCUSSIONS 3.1 Results}

Interventions are performed on early childhood in Pelangi Nusantara Early Childhood School and Aisyiah 38 Pre-School Gunungpati District of Semarang. The number of children are 32, with the number of boys are more (about 20\%) compared by the girls. Ages between 2-4 years, the most at age 3-4 years which is $78.1 \%$ (Table 1 ).

Table 1. Distribution of Early Childhood by Age and Gender.

\begin{tabular}{|c|c|c|c|c|c|c|c|c|}
\hline \multirow{3}{*}{ Gender } & \multicolumn{6}{|c|}{ Age (years) } & \multicolumn{2}{|c|}{ Total } \\
\hline & \multicolumn{2}{|c|}{$<3$} & \multicolumn{2}{|c|}{$3-4$} & \multicolumn{2}{|c|}{$>4$} & \multirow{2}{*}{$\mathrm{n}$} & \multirow{2}{*}{$\%$} \\
\hline & $\mathrm{n}$ & $\%$ & $\mathrm{n}$ & $\%$ & $\mathrm{n}$ & $\%$ & & \\
\hline Male & 2 & 6,3 & 15 & 46,9 & 2 & 6,3 & 19 & 59,4 \\
\hline Female & 1 & 3,1 & 10 & 31,3 & 2 & 6,3 & 13 & 40,6 \\
\hline Total & 3 & 9,4 & 25 & 78,1 & 4 & 12,5 & 32 & 100,0 \\
\hline
\end{tabular}

All the early childhood's mothers and teachers were involved in interventions, which is 37 persons. The intervention is needed, especially for parents. Table 2 show that nutrition and health knowledge score increased quite a lot that is 21.7. After early childhood intervention, no mother is in the category of less, but instead 24.3 percent increased to excellent.

Table 2. Early Childhoods' Mothers and Teachers' Knowledge ofNutrition andHealth Before and After Intervention.

\begin{tabular}{|c|c|c|c|c|c|c|c|}
\hline \multirow{2}{*}{ Categories } & \multicolumn{3}{|c|}{ Before Intervention } & \multicolumn{3}{|c|}{ After Intervention } & \\
\hline & $\mathrm{n}$ & $\%$ & $\bar{X} \pm S D$ & $\mathrm{n}$ & $\%$ & $\bar{X} \pm S D$ & \\
\hline Decifient & 27 & 73,0 & $52,1 \pm 7,1$ & 0 & 0 & 0 & \\
\hline Passably & 5 & 13,5 & $65,6 \pm 2,2$ & 3 & 8,1 & $65,3 \pm 2,3$ & \\
\hline Good & 5 & 13,5 & $74,4 \pm 3,6$ & 25 & 67,6 & $77,7 \pm 4,5$ & \\
\hline Excellent & 0 & 0 & 0 & 9 & 24,3 & $90,2 \pm 2,1$ & \\
\hline Total & 37 & 100,0 & $57,1 \pm 11,1$ & 37 & 100,0 & $78,8 \pm 7,8$ & \\
\hline $\begin{array}{l}\text { in Table } 2 \\
\text { ement of moth } \\
\text { nutrition and } \\
\text { the group of } \\
\text { omen are incre } \\
d \text { health into } \\
\text { of categories. } \\
\text { owledge as mu }\end{array}$ & $\begin{array}{l}\text { entec } \\
\text { now } \\
\text { is } \\
\text { ient } \\
\text { heir } \\
\text { cate } \\
\text { arly, }\end{array}$ & $\begin{array}{l}\text { Figure } \\
\text { of ear } \\
\text { enoug } \\
\text { gories. } \\
\text { vledge } \\
\text { jump } \\
\text { excelle }\end{array}$ & $\begin{array}{l}80,0 \\
70,0 \\
60,0 \\
50,0 \\
40,0 \\
30,0 \\
20,0 \\
10,0\end{array}$ & & 73,0 & 24,3 & $\begin{array}{l}\text { Before } \\
\text { Interventio } \\
n \\
\text {-After } \\
\text { Interventio } \\
n\end{array}$ \\
\hline
\end{tabular}

The data in Table 2 is presented in Figure 1. The improvement of mothers' knowledge of early childhood's nutrition and health is sharp enough, especially in the group of deficient categories. A $73.0 \%$ of women are increased their knowledge of nutrition and health into good category, jumped two levels of categories. Similarly, the excellent category knowledge as much as $24.3 \%$.
Figure 1. Knowledge of Nutrition and Health's Average Before and After Intervention. 
Effectiveness of interventions on improving nutrition and health knowledge can be seen from the $\mathrm{N}$-gain with a mean score of 0.50 in the medium category. Pair samples t-test results of showed the value of $p=0.00$, which means there is a significant increase in nutrition and health education interventions on nutrition and health knowledge.
Research on interventions on snack food showed similar results, with a decrease in the deficient category and the passably category rised to the good and very good categories. The results were very encouraging, mothers have noticed snack food to their children, as many as 90.4 mother has an excellent knowledge of snack food (Table 3).

Table 3. Early Childhood's Mother's and teacher's Knowledge of Snack Food Before and After Intervention.

\begin{tabular}{lcccccc}
\hline \multirow{2}{*}{ Categories } & \multicolumn{3}{c}{ Before Intervention } & \multicolumn{2}{c}{ After Intervention } \\
\cline { 2 - 7 } & $\mathrm{n}$ & $\%$ & $\bar{X} \pm S D$ & $\mathrm{n}$ & $\%$ & $\bar{X} \pm S D$ \\
\hline Deficient & 6 & 16,2 & 60 & 0 & - & - \\
\hline Passably & 6 & 16,2 & 67 & 1 & 2,7 & 67 \\
\hline Good & 11 & 29,7 & $75,5 \pm 3,5$ & 9 & 24,3 & $78,4 \pm 3,1$ \\
\hline Excellent & 14 & 37,8 & $87,8 \pm 3,1$ & 27 & 73,0 & $90,4 \pm 3,6$ \\
\hline \multicolumn{1}{c}{ Total } & 37 & 100,0 & $76,9 \pm 11,6$ & 37 & 100,0 & $86,8 \pm 7.0$ \\
\hline
\end{tabular}

Figure 2 shows the increase of the percentage of mothers in all categories in knowledge of snack food. About 30 percent of women who in the deficient and passably category was rise to the category of the good and excellent.

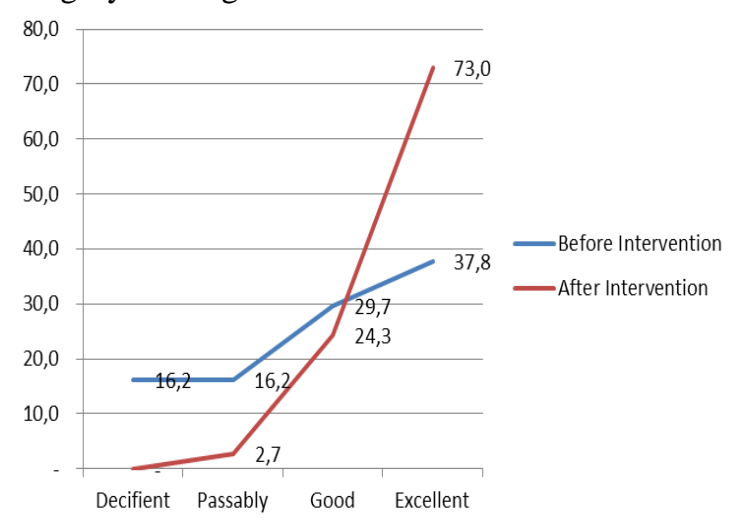

Figure 2. Knowledge of Snack Food's Average Before and After Intervention.
The improvement of snack food's knowledge is shown by the pair test sample t-test with $\mathrm{p}=0.000$. In addition, $\mathrm{N}$-gain value that measures the effectiveness of improvement obtained with category average of 0.34 . There were $9(24.3 \%)$ of mothers who did not experience an increase in snack food's knowledge scores on most mothers has an excellent score.

The different results occurred in the measurement of early childhood's nutritional status. Not many changes in early childhood's nutritional status, but there are developments in a positive direction. Table 5 shows status of wasting decreased $6,2 \%$ and the nutritional status of normal increased $6,2 \%$.

Table 4. Early Childhood's Nutritional Status Before and After Intervention.

\begin{tabular}{lcccccc}
\hline \multirow{2}{*}{ Categories } & \multicolumn{3}{c}{ Before Intervention } & \multicolumn{2}{c}{ After Intervention } \\
\cline { 2 - 7 } & $\mathrm{n}$ & $\%$ & Categories & $\mathrm{n}$ & $\%$ & Categories \\
\hline severe wasting & 0 & - & & 0 & - & 0 \\
\hline wasting & 4 & 12,5 & 12,7 & 2 & 6,3 & 12,4 \\
\hline Normal & 27 & 84,4 & $15,2 \pm 1,9$ & 29 & 90,6 & $14,8 \pm 1,6$ \\
\hline Obesity & 1 & 3,1 & 22,6 & 1 & 3,1 & 20,5 \\
\hline Total & 32 & 100,0 & $15,2 \pm 1,9$ & 32 & 100,0 & $14,8 \pm 1,6$ \\
\hline
\end{tabular}


The early childhood who's experiencing malnutrition increased to normal or good and the fat early childhood also become normal or good. These conditions make early childhood more healthy or well-nourished. Good nutritional status as much as $90,4 \%$ children. $\mathrm{N}$-gain cannot be calculated for nutritional status, because the standard of nutritional status of different age groups (monthly changes) and standard malnutrition status leads to a smaller value while the nutritional status leads to a value greater than the standard value, or median. Therefore, the calculated pair sample t-test and obtained the value $p=0.041$ in the category of very significant.

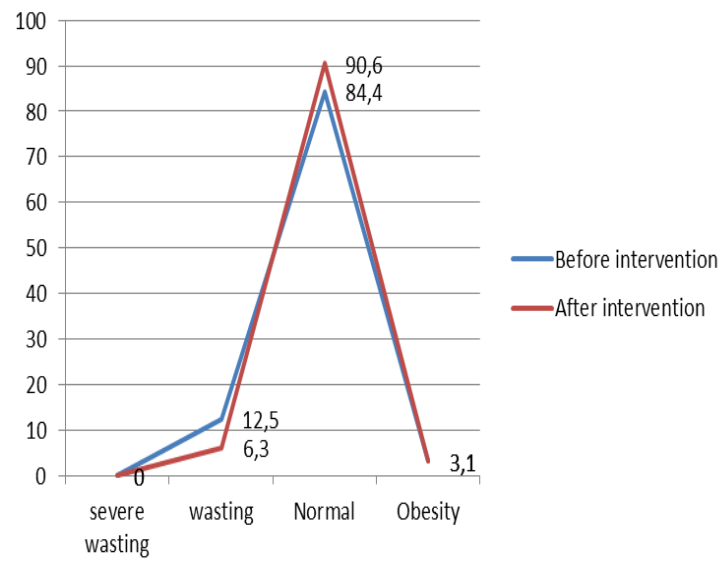

Figure 3. Early Childhood's Nutritional Status Before and After Intervention

\subsection{Discussions}

The number of early childhoods who participate in early childhood education is more boys than girls. It shows that boys are more dominant parents' concern in early education. Most who are in early childhood education ages 3-4 years which is $78.1 \%$. Gross enrollment in early childhood programs ages 0-6 years showed that only reached $50.62 \%$ (EFA Secretariat, 2009).

Early childhood's mothers and teachers' knowledge of nutrition and health increased significantly $(\mathrm{p}=0.000)$ with the effectiveness of $\mathrm{N}$-gain 0.50. It shows the nutritional and health education interventions have been successful in increasing knowledge of nutrition and good health. The mothers claimed this education activity is very appropriate and beneficial for child care so that their children can be healthier. This is consistent with research in several countries shows the results in a positive direction. The results of the study in the Sukaraja sub-district and South Bogor district on mothers about the counseling package leaflet given for 3 months showed significant differences $(\mathrm{p}=0.008)$ on the attitude of the mothers (Salimar, 2005). Research providing counseling to the mother of malnourished children in Tasikmalaya shows that there are differences in knowledge of the mother before and after counseling with $\mathrm{p}=$ 0.000 ( $p$ value <a). The average score of the mother's knowledge after counseling is higher at 51.32 points compared to the score of knowledge of mothers before counseling namely 38.27 points (Lina and Hadayani, 2015). Nutrition education intervention on a group of athletic men in Florida can improve nutritional knowledge $(p<0.05)$ and overall change eating habits in a positive direction ( $\mathrm{p}<0.03$ ) (Aboot, Black, and Brinbaum, 2004). Other studies at Indiana community given nutrition education and food or Food Stamp Nutrition Education (FSNE) additionally received the results of food insecurity and inadequate food in the experimental group were significantly increased ( $p$ $=0.03$ and $\mathrm{p}=0.04)$ when compared to group control (Miller, et.al, 2009). Intervention of NAP SACC (Nutrition and Physical Activity SelfAssessment for Child Care) in California showed a significant increase in knowledge of nutrition and physical activity of the child care providers and parents, the center of policy development, and changes in child's BMI (Alkon et al. 2014).

The same thing happened on the knowledge of snack food. Knowledge of snack food increased significantly $(p=0.000)$ and the effectiveness of $\mathrm{N}$-gain 0.34 . It shows that mother plays an active role in the management of children's snack food. The contribution of snack food to the nutritional adequacy is quite large. In accordance with the results of research on early childhood snack food in Semarang which consumed 20 kinds, with five first order milk, biscuits, bread, fruit, and wafers. The nutrient content of energy, protein, and iron snack food consumption amounted to $518 \mathrm{kcal}$, $17.1 \mathrm{~g}$, and $4.2 \mathrm{mg}$, with the contribution of nutrients is high enough in meeting the nutritional adequacy of energy $43.5 \%$, protein $62.3 \%$ and $56.0 \%$ iron. The largest contribution came from milk, the percentage of energy, protein and iron milk from snack food consumption, respectively for $44.9 \%, 62.1 \%$ and $80.5 \%$. (Fathonah, Rosidah, and Sarwi, 2014).

The nutritional status of two early childhood education studied are in the quite well category. Before the intervention and after the intervention of the normal percentage of children respectively 78.1 and $87.5 \%$. Meanwhile after the intervention 
AUD malnutrition $6.3 \%$ and $3.1 \%$ obese and very obese $3.1 \%$. It shows most of the early childhood are in the good health condition. This number was better than the national's number. Data Basic Health Research (Riskesdas) in 2010, the number of patients with less severe among young children or toddlers $17.9 \%$ consists of $4.9 \%$ malnutrition and $13.0 \%$ less-nutrition, while obesity prevalence of $14 \%$ (Ministry of Health, 2013). Conditions in developed countries nutritional status is higher. Excess nutrients in school children in Australia $25 \%$ (Booth, 2004) and 20\% of pre-school age children (Wake, 2007), and around 30\% in the United States and 20\% in the Europe (Lobstein, 2004).

The biscuits were given to the early childhood for 30 days, is biscuits with basic ingredients of local food. Biscuits with corn $(60 \%)$, purple parsnip (50\%), and green beans (50\%) belongs to the category of energy-dense biscuits with an energy contents more than $400 \mathrm{kcal}$, protein content and high fiber too (Fathonah and Sari, 2015 and Fathonah and Muvida, 2015). The best corn biscuits are on the use of 35\% margarine (Fathonah, Sarwi and Rosidah, 2015), best purple parsnip biscuits are on the use of 55\% margarine (Fathonah and Sari, 2015), as well as green beans biscuits are on the use of 35\% margarine (Fathonah and Muvida, 2015). The content of beta-carotene is high enough in corn biscuits between 2721-4134 ppm (Fathonah, Sarwi and Rosidah, 2015). Betacarotene is one carotene which has the function of an antioxidant and helps protect the nutrients are easily oxidized, such as PUFAs, from oxidation and able to resist the harmful effects of free radicals in the body (Lean, 2013). The amount of fat is green beans biscuits $(22.2-24.6 \%)$, purple sweet parsnip biscuits (24.9 -25.5\%), and corn biscuits (from 18.2 to $21.7 \%$ ) is still within reasonable limits, because the results of the study 12 kinds of biscuits circulating in Pakistan found the fat content varies from $13.7-27.6 \%$ (Kandhro, Sherazi, MAHESAR, Bhanger, Talpur, and, Arain, 2008). The results of the analysis of 46 samples of biscuits sold in the Indian market showed a fat content ranging from 9.5 to $25.0 \mathrm{~g} / 100 \mathrm{~g}$ of biscuits (Kala, 2014) While the 6 types of biscuits manufactured by four companies in Turkey, the fat content ranging between $8.5 \%$ and $26.0 \%$ (Daglioglu, Tasan, and Tuncel, 2000).

\section{CONCLUSIONS AND SUGGESTIONS}

Based on the results of the study can be summarized as follows:

- Nutrition and health education interventions to mothers, teachers, and children were able to increase the knowledge of nutrition and health significantly, with $\mathrm{N}$-gain 0.50 .

- Nutrition and health education interventions to mothers, teachers, and children were able to increase the knowledge of snack food significantly, with $\mathrm{N}$-gain 0.34 .

- By the nutrition and health education interventions on early childhood's teachers and mothers and provision of energy-dense biscuits during the 30-day impact on the early childhood's nutritional status leads to normal nutrition, nutritional status differed significantly between before and after the intervention $(p=0.041)$.

Suggestions can be put forward are 1) expanding coverage of nutrition and health education interventions and the provision of energy dense biscuits on the early childhood with wider coverage, 2) need to increase the active participation of early childhood's parents in intervention activities.

\section{REFERENCES}

Alkon et. al. (2014). Nutrition and physical activity randomized control trial in child care centers improves knowledge,policies, and children's body mass index. BMC Public Health, 14, 1-13.

Abood, D.A, D.R. Black, and R.D. Birnbaum. (2004). Nutrition Education Intervention for College Female Athletes. Journal of Nutrition Education and Behavior. 36 (3), 135-139.

Booth ML, Dobbins T, Okely AD, Denney-Wilson E, Hardy LL. (2007). Trends in the prevalence of overweight and obesity among young Australians, 1985, 1997, and 2004. Obesity (Silver Spring) 2007, 15 (5). 1089-1095.

Daglioglu, O, M. Tasan, and B. Tuncel. (2000). Determination of fatty acid composition and total trans fatty acids of Turkish biscuits by capillary gas-liquid chromatography. European Food Research and Technology, 211 (1), 41-44.

Fathonah, S., Rosidah, and sarwi. (2014). Nutritional Adequacy Level of Snack toward Nutritional Status of Early Childhood. Greener Journal of Epidemiology and Public Health. 2 (2), 037-044.

Fathonah, S., dan F. Sari. (2015). Purple Sweet Potato Biscuits with Different Margarine Usage. Proceeding of International Conference on Green Technology. Semarang: Unnes Press. 
Fathonah, S, Sarwi, dan Rosidah. (2015). Pengembangan Sumber daya Anak Usia Dini Dengan Pendidikan Gizi Dan Konsumsi Biskuit Padat Energi Berbasis Pangan Lokal. Laporan Penelitian. Unnes. Semarang.

Fathonah, S., dan F. Muvida. (2015). Mung Bean Biscuits for Early Childhood. Proceeding of 1st Unnes International Conference on Research Innovation \& Commercialization for the Better Life 2015. Semarang: LP2M.

Hake. (1998). Interactive-engagements traditional methods: A six-thousand-student survey of mechanics test data for introductory physics courses. Am.J.Phys. 66, 64-74.

Jalal, F. (2002). Pendidikan Anak Dini Usia: Pendidikan Yang Mendasar. Jurnal Ilmiah PAUD, 4-8.

Jancey et al. (2014). Dietary outcomes of a community based intervention for mothers of young children:a randomised controll edtrial. International Journal of Behavioral Nutrition and Physical Activity, 11, 1-9.

Jukes, M. (2007). Better education through improved health and nutritoi $\mathrm{n}$ : implications for early childhood development programs in developing countreis. Pediatric Infectious Diseases Revisited, 145-176.

Kadir. (2015). Statistika Terapan. Jakarta: Raja Grafindo Persada.

Kala. A. L. A. (2014). Studies on saturated and trans fatty acids composition of few commercial brands of biscuits sold in Indian market. Journal of Food Science and Technology. 51 (11), 3520-3526.

Kandhro,A,S.T. H. Sherazi, S. A. Mahesar, M. I. Bhang er, M. Y. Talpur, and, S. Arain. (2008). Monitoring of Fat Content, Free Fatty Acid and Fatty Acid Profile Includingtrans Fat in Pakistani Biscuits. Journal of the American Oil Chemists' Society, 85 (11), 1057-1061.

Kementerian Kesehatan RI. (2013). Riset Kesehatan Dasar. Jakarta: Kementerian Kesehatan.

Kulwa et al. (2014). Effectiveness of a nutrition education package in improving feeding practices, dietary adequacy and growth of infants and young children in rural Tanzania: rationale, design and methods of a cluster randomised trial. BMC Public Health, 14 (1077), 1-16.

Lakshman et, al. (2010). A novel school-based intervention to improve nutrition knowledge in children: cluster randomised controlled trial. $B M C$ Public Health, 10 (123), 1-9.

Lean, M.E. (2013). Ilmu Pangan, Gizi dan Kesehatan. Terjemahan. Yogyakarta: Pustaka Pelajar.

Lina, N dan L. Hidayanti. (2015). Analisis Dampak Konseling Gizi Terhadap Peningkatan Pengetahuan Gizi Ibu yang Memiliki Balita Gizi Kurang. Jurnal Kesehatan Komunitas Indonesia. 11 (1).

Lobstein T, Baur L, Uauy R. (2004). Obesity in children and young people: a crisis in public health. Obes Rev 2004, 5(1), 54-104.

Mahmudiono et al. (2016). The effectiveness of nutrition education for overweight/obese mothers with stunted children (NEO-MOM) in reducing the double burden of malnutrition in Indonesia: study protocol for a randomized controlled trial. BMC Public Health, 16 (486), 1-11.

Miller, H.A.E, A.C. Mason, A.R. Abbott, G.P. McCabe and C.J. Boushey. (2009). The Effect of Food Stamp Nutrition Education on the Food Insecurity of Lowincome Women Participants. Journal of Nutrition Education and Behavior. 41 (3), 161-168.

Salimar. (2005). Peranan Penyuluhan Dengan Menggunakan Alat Bantu Leafleat Terhadap Perubahan Pengetahuan Dan Sikap Ibu Balita Gizi Kurang. Laporan Penelitian.

Sekretariat Pendidikan untuk Semua. (2009). Draft Laporan Rapat Kerja Nasional Pendidikan Untuk Semua (PUS). Jakarta: Sekretariat Pendidikan.

Steyn et al. (2015). Did Health Kick, a randomised controlled trial primary school nutrition intervention improve dietary quality of children in low-income settings in South Africa? BMC Public Health, 15 (948), 1-11.

Wake M, Nicholson JM, Hardy P, Smith K. (2007). Preschooler obesity and parenting styles of mothers and fathers: Australian national population study. Pediatrics, 120 (6), 1520-1527. 